\title{
Statement of Financial Accounting Standard No.34 Applied in Recognition of Revenue in the North Jakarta Breakwater Construction Project by PT Mina Fajar Abadi
}

\author{
Tommy Kuncara ${ }^{1}$, Ibnu Haris Nasution ${ }^{2}$ \\ \{tommy_kuncara@staff.gunadarma.ac.id ${ }^{1}$, ibnu.haris.nasution@undira.ac.id ${ }^{2}$ \} \\ Accounting Departemen, Faculty of Economy, Universitas Gunadarma, Jakarta, \\ Indonesia ${ }^{1}$, Management Department, Faculty of Economy and Business, \\ Universitas Dian Nusantara, West Jakarta, Jakarta, Indonesia ${ }^{2}$
}

\begin{abstract}
Construction service companies have distinctive characteristics, where not all of the project work processes are completed in one accounting period, and the commencement of work cannot be ensured at the beginning of the year, depending on the contract of the agreed construction work contract. There are several methods that can be used by construction companies in recognizing their income, and we know that income is one of the components of profit formation. Revenue must be measured fairly and must be confirmed in accordance with revenue recognition and the principles of the Statement of Financial Accounting Standards. PT. Mina Fajar Abadi uses the basis of cash in recognizing her income, which is by recording income and expenses in the income statement when cash is received or paid, it is not in accordance with the Statement of Financial Accounting Standards on construction services. If the project is carried out the total revenue and contract expenses can be measured reliably, then the company should apply the percentage of completion method in recognizing its income, thus the income statement presented by the company will provide the right information for decision making for the company.
\end{abstract}

Keywords: Revenue Recognition, Settlement Method, PSAK No.34

\section{Introduction}

At a glance, the type of construction contract business is not much different from other business activities, with costs, income and then profit or loss. But if you have entered it, of course there are differences in determining accounting treatment [1]. What scope is most suitable for this construction contract business. How income and expenses are treated in a construction contract business is, of course, different from the treatment of income and expenses in other businesses. This difference occurs because the activities carried out in construction contracts are indeed very different from other types of business [2].

In particular, the date on which contract activity begins and the date when the activity is completed usually fall on different accounting periods [3]. Accounting standards have been established for the accounting treatment of construction contract businesses, so in handling accounting matters relating to construction contracts, the accountant must Therefore, the understanding of the accounting treatment of construction contracts is in accordance with applicable accounting standards, in particular the Statement of Financial Accounting Standards (PSAK) No. 34 of the required Construction Contracts [4]. 


\section{Literature Review}

\subsection{Financial Statements}

According to SFAS No. 1 of 2015, Financial Statements are structured presentations of the financial position and financial performance of an entity. This report displays the history of the entity that is quantified in monetary value. Financial reports are part of the financial reporting process. According to The Indonesian Institute of Accountants, (IAI), [5] the purpose of this financial report for the public interest is the presentation of information on financial position, financial performance, and cash flow from very large entities. useful for making economical decisions for its users. In order to achieve this objective, financial statements provide information about the elements of the entity consisting of the assets, liabilities, Capital, expenses, and income (including gain or loss), changes in equity and cash flow. The information, followed by notes, will help users predict future cash flows. [6]

\subsection{Income}

Income is an increase in economic benefits during a certain accounting period in the form of income or addition of assets or decrease in liabilities which results in an increase in equity that does not come from investment contributions. An increase in the number of assets or a decrease in liabilities may result from the delivery of goods / services or other business activities in one period. [7]

\subsection{Construction Contract}

According to PSAK 34 (Revised 2010), "A construction contract is a contract specifically negotiated for the construction of an asset or a combination of assets that are closely related to one another or interdependent in terms of design, technology, and function or purpose or principal use. [8]

" From the above definition, it can be concluded that a construction contract is an agreement or negotiation between the project owner and agents to coordinate all project activities with the aim of minimizing costs and schedules and maintaining project quality [9].

There are two accounting methods used for construction contracts proposed, namely:

1. The percentage of completion method.

Under this method, revenue is recognized progressively for each period according to the level of completion of the transaction at the reporting date. Contract revenue is related to contract costs incurred in reaching the completion stage, so that the reported expenses and profits can be proportionally attributed according to the completion of the work [10].

2. The contract method is complete.

In the completed contract method, the costs of the contract that are worked out are accumulated and no charges are made on the income, expenses and gross profit accounts until the contract is completed. With this method, the contracting company recognizes revenue at once when the contract is completed, so that revenues and expenses / expenses are known with certainty [11].

\subsection{Income Recognition According to PSAK No. 34}

In Financial Accounting Standards No. 34, recognition is the process of forming an item that meets the definition of an element and the recognition criteria in the balance sheet and profit or loss. Recognition is made by stating the item in words and in the amount of money and including it in the balance sheet or profit or loss. Items that meet these criteria must be recognized in the balance sheet or income statement. Failure to recognize such items cannot be rectified by disclosing the accounting policies used or by notes or explanatory material [6]. 


\section{Methods}

To find out how much influence the use of revenue recognition method has on profit, in this study the authors use the following analysis tools [12]:

a. Descriptive Analysis,

Performing analysis techniques that describe thoroughly the income accounting for construction contracts implemented by PT. Mina Fajar Abadi during.

b. Qualitative Analysis

Doing a comparison between the existing theories with actual practice so that visible differences in recording happened and how to solve them.

c. Quantitative Analysis The quantity of

data that has been collected is calculated and uses the calculation of revenue recognition in commonly used data processing using the appropriate calculation method in PSAK No. 34.

\section{Result and Discussion}

PT. Mina Fajar Abadi is a company engaged in construction services. PT. Mina Fajar Abadi is a continuation of the business of the Limited Liability Company CV. Mina Fajar Abadi is domiciled in East Aceh Regency and was established by virtue of a deed dated June 7, 2000. PT. Mina Fajar Abadi itself was founded in 2007, which is located at Jl. Kuala Bagok Hamlet Mesjid Gampong Keude Bagok Nurussalam, East Aceh.

An overview of how the income accounting applied by PT. Mina Fajar Abadi. The author takes a sample of recording construction contract revenue based on the PT. Mina Fajar Abadi with the Food, Maritime and Agricultural Security Service of DKI Jakarta Province, in accordance with the Work Agreement Letter No. 2897 / 076-3, dated April 1, 2019. Based on this Agreement, the following information can be obtained:

1. Contract date April 1, 2019

2. Implementation period April 1, 2019 to November 26, 2019

3. Contract Value of Rp. 39,762,142,376

4. Fines, the amount of fines imposed on the Provider for late completion of work for each day of delay is $1 / 1000$ (one thousandth) of the remaining part of the contract price that has not been completed if the part of the work that has been carried out can function.

Illustrated by PT. Mina Fajar Abadi obtained a construction contract job, namely a project for the manufacture of a Break water located in the Nusantara Muara Angke Fishery Port Area, DKI Jakarta Province. In this case, the company makes a contract agreement in which the company is the 2nd party and the project implementer. The contract value agreed is Rp. 39,762,142,376. The project implementation time is estimated to be 240 days, from April to November 2019. follows

Based on the statement of the Contract, the transactions recorded by PT. Mina Fajar Abadi is as

1) Receipt of the first instalment payment (Term I) of 20\% on May 23, 2019, so that the first term bill is $20 \%$ multiplied by the Contract Price (20\% x Contract Price)

After work performance has reached $(20 \%))=$ Rp. 7,952,428,475

2) Receipt of the second instalment payment (Term II) of $30 \%$ on July 22, 2019, so that the second term bill is $30 \%$ multiplied by the Contract Price (30\% x Contract Price)

After work performance has reached $(50 \%)=\mathrm{Rp} .11,928,642,713$

3) Receipt of the third instalment payment (Termin III) of 25\% on September 3, 2019, so that the third term bill is $25 \%$ multiplied by the Contract Price $(25 \%$ x Contract Price 
After work performance has reached $(75 \%)=\mathrm{Rp} .9,940,535,594$

4) Receipt of the last instalment payment (Term IV / Repayment) of 25\% on December 2, 2019, so that the last term bill is $25 \%$ multiplied by the Contract Price (25\% x Contract Price)

After work performance has reached $(100 \%)=$ Rp. 9,940,535,594.

\section{Income Recognition According to PSAK No. 34}

According to PSAK No. 34 paragraph 10, income is measured at the fair value to be received, whereas in paragraph 20 , it is stated that contract statements and contract costs related to construction contracts should be recognized as revenue and expenses, respectively, with due regard to the stage of completion of contract activity at balance sheet date [13].

Based on PSAK No. 34, we can calculate the recognition of income during the construction process as follows

Billing Of Payment For Termination I in May 2019

I (20\% x IDR. 39,762,142,376) Rp. 7,952,428,475

$5 \%$ retention IDR. $(397,621,424)$

Net Hospitalization IDR. 7,554,807,051Term

VAT (10\% bill) IDR. 795,242,848

Total Claims IDR. 8,350,049,899

Journal of Income Recognition for May 2019

(dr) Accounts Receivable IDR. 8,350,049,899

(dr) Project Retention IDR. 397,621,424

(cr) Progress of invoice for contract IDR. 7,952,428,475

(cr) Output VAT IDR. 795,242,848

Journal of Receipt of Claims for Termination 1 of May 2019

(dr) Cash

IDR. 8,350,049,899

(cr) Accounts Receivable IDR. 8,350,049,899

Billing Of Payment For Termination II of July 2019

II bill (30\% x IDR. 39,762,142,376) IDR. 11,928,642,713

$5 \%$ retention IDR. $(596,432,136)$

Net Opname IDR. 11,332,210,577Term

VAT (10\% bill) IDR. 1,192,862,271

Total Claims IDR. 12,525,072,848

Journal of Income Recognition for July 2019

(dr) Accounts Receivable IDR. 12,525,072,848

(dr) Project Retention IDR.596,432,136 
(cr) Progress of invoice for contract IDR. 11,928,642,713

(cr) Output VAT IDR. 1,192,862,271

Journal of Receipt of Claims for Termination II of July 2019

(dr) Cash IDR. 12,525,072,848

(cr) Accounts Receivable IDR. 12,525,072,848

Billing Of Payment For Termination III in September 2019

III (25\% x IDR. 39,762,142,376) IDR. 9,940,535,594

$5 \%$ retention IDR. $(497,026,780)$

Net Hospitalization IDR. 9,443,508,814Term

VAT (10\% bill) IDR. 994,053,559

Total Claims IDR. 10,437,562,373

Journal of Income Recognition for September 2019

(dr) Accounts Receivable IDR. 10,437,562,373

(dr) Project Retention IDR. 497,026,780

(cr) Progress of invoice for the contract IDR. 9,940,535,594

(cr) Output VAT IDR. 994,053,559

Journal of Receipt of Claims for Termination III of September 2019

(dr) Cash IDR. 10,437,562,373

(cr) Accounts Receivable IDR. 10,437,562,373

Billing Of Payment For Termination IV December 2019

Bill (25\% x IDR. 39,762,142,376) Rp. 9,940,535,594

$5 \%$ retention IDR. $(497,026,780)$

Net Hospitalization IDR. 9,443,508,814Term

VAT (10\% bill) IDR. 994,053,559

Total Claims IDR. 10,437,562,373

Journal of Income Recognition for December 2019

(dr) Accounts Receivable Rp. 10,437,562,373 
(dr) Project Retention IDR. 497,026,780

(cr) Progress of invoice for the contract IDR. 9,940,535,594

(cr) Output VAT IDR. 994,053,559

Journal of Receipt of Claims for Termination IV of December 2019

(dr) Cash IDR. 10,437,562,373

(cr) Accounts Receivable IDR. 10,437,562,373

Journal of retention collection of the terms of each month which is done at the end of the period after the handover of the Minutes

(dr) Accounts Receivable IDR. 9,940,535,594

(cr) Project Retention IDR. 9,940,535,594

Journal of retention receipts that will still be received from collection

(dr) Cash IDR. 9,940,535,594

(cr) Accounts Receivable IDR. 9,940,535,594

Based on the above calculations, the recognition of income according to PSAK. No. 34 is recognized based on the percentage progress achieved in the minutes. In addition, using themethod accrual basis in recognizing revenue when the revenue is generated, for example, revenue is reported when services are provided to customers during the period concerned.

Differences in Project Income between Companies and PSAK No. 34

\begin{tabular}{lccc}
\hline Descriptions & by & According to & Difference in \\
& Company & PSAK No.34 & \\
\hline
\end{tabular}

May '19

Revenue

July' 19

$\begin{array}{ll}\text { Rp. } 7,952,428,475 & \text { Rp. } 8,350,049,899\end{array}$

Rp. $397,621,424$

Income

Rp.

$11,928,642,713$

Rp. $12,525,072,848$

Rp. 596,430,135

September'19

Income

$\begin{array}{ll}\text { Rp. } 9,940,535,594 & \text { Rp. } 10,437,562,373\end{array}$

Rp. $497,026,779$ 


\section{December'19}

Income

$\begin{array}{lll}\text { Rp. } 9,940,535,594 & \text { Rp. } 10,437,562,373 & \text { Rp. } 497,026,779\end{array}$

From the table above, it is known that the recognition of company revenue for the months of May, July, September, and December 2019 is recognized as lower than the income calculation applied in accordance with the Statement of Accounting Standard No. 34, this is because PT. Mina Fajar Abadi still admits that her income is on a cash basis. In the construction work contract that has been agreed upon, the company receives less revenue for each term than the progress that has been made. So in this case, the recognition of revenue by PT. Mina Fajar Abadi is still not in accordance with PSAK No. 34.

\section{Conclusion}

Based on the analysis and discussion that has been conducted on PT. Mina Fajar Abadi, it can be concluded that the following are:

1. PT. Mina Fajar Abadi, for all projects worked on admits income based on work progress or better known as the percentage of completion method. The percentage of completion is measured usingoutput measuresdetermined by the experts and operations section in the form of project achievement reports, this is adequate and in accordance with the applicable Financial Accounting Standards, however in practice there are other obstacles, namely PT. Mina Fajar Abadi uses the basis of physical work progress to calculate the amount of income that will be recognized. The company uses the terms of payment or cash received from the employer as revenue recognized by the company.

2. The company does not record project costs based on physical progress, but the company records the costs incurred in a one-time project that is accumulated when the project is completed and uses theconcept all-inclusive where all expenses related directly and indirectly are all recorded and recognized in income statement. Company continues to acknowledge a 5\% retention which will be paid by the employer when the project is $100 \%$ completed. The process of recording all transactions in the financial statements uses cash bassis where all transactions are directly entered into the company's cash account. There are significant differences in recognizing revenue according to companies and according to PSAK No. 34. The basis for recognizing company revenue is the receipt of cash that has been paid by the client from the agreed construction work contract, not based on the progress that has been completed.

\section{References}

[1] R. Wahasusmiah, "Analisis Penerapan Pajak Penghasilan Atas Jasa Konstruksi dan Kesesuaian Standar Akuntansi Kontrak Konstruksi (PSAK No. 34),” ACSY Politek. Sekayu, 2018.

[2] E. Nurjanah, "PENGAKUAN PENDAPATAN DENGAN METODE PERSENTASE PENYELESAIAN BERDASARKAN PSAK NO.34,” El Muhasaba J. Akunt., 2016, doi: 10.18860/em.v7i1.3882.

[3] J. Andres and R. P. Pardede, “Analisis Penerapan Cost Recovery Method Dan Percentage Of Completion Method Berdasarkan PSAK 34 Terhadap Laba Kotor Perusahaan PT Mitra Menara Mandiri,” J. Ilm. Akunt. Kesatuan, 2018, doi: 10.37641/jiakes.v6i2.137.

[4] M. Hidayat, "Analisis Pengakuan dan Pengungkapan Pendapatan Pada Laporan Keuangan PT. Adhi Karya (Persero Tbk) Berdasarkan PSAK 23, PSAK 34, PSAK 44,” J. Meas., 2016.

[5] Ikatan Akuntan Indonesia, Standar Akuntansi Keuangan Entitas Tanpa Akuntabilitas Publik (SAK 
ETAP. Jakarta: Ikatan Akuntan Indonesia, 2019.

[6] S. Pinatik, J. Sondakh, and M. Andaki, “ANALISIS PERBANDINGAN PENGAKUAN PENDAPATAN DAN PEMBEBANAN BIAYA MENURUT STANDAR AKUNTANSI KEUANGAN DAN UNDANGâUNDANG PERPAJAKAN PADA PERUSAHAAN JASA KONSTRUKSI (Studi Pada PT. Anugrah Adyatama, Jakarta)," J. Ris. Ekon. Manajemen, Bisnis dan Akunt., 2015.

[7] P. C. Oroh, "Evaluasi Penerapan Psak No.34 (Revisi 2010) Dalam Pengakuan Dan Pengukuran Pendapatan Usaha Jasa Konstruksi Pada Cv. Surya Gemilang Utama," J. Ris. Ekon. Manajemen, Bisnis dan Akunt., 2013.

[8] Rismansyah and S. Nurlaili, “Analisis Pengakuan Pendapatan Dan Beban Pada PT. Wahana Bumi Riau Cabang PALEMBANG (Rismansyah \& Nurlaili Safitri),” Akuntansi, 2014.

[9] D. P. E. S. Dhullo Afandi, Feris Kristian Tikupadang, "ANALISIS PENERAPAN AKUNTANSI KONTRAK KONSTRUKSI DALAM PENYAJIAN LAPORAN KEUANGAN PADA PT. SEDERHANA KARYA JAYA DI MANADO,” J. Berk. Ilm. EFISIENSI, 2016.

[10] C. Liawan and V. N. VAN HARLING, "ANALISIS PERLAKUAN AKUNTANSI PENDAPATAN JASA KONSTRUKSI PADA PT. AGRINDO MAKMUR ABADI," SOSCIED, 2019, doi: 10.32531/jsoscied.v2i1.169.

[11] Kieso, Weygandt, and Warfield, Akuntansi Keuangan Menengah Intermediate Accounting. 2018.

[12] B. Bryan and H. Hastoni, "Evaluasi Pengakuan Pendapatan dan Beban Kontrak serta Pengaruhnya Terhadap laba Perusahaan Konstruksi Sesuai PSAK 34 Revisi 2010,” J. Ilm. Akunt. Kesatuan, 2013, doi: 10.37641/jiakes.v1i3.242.

[13] R. Subagja and D. Pradipto, “Analisis Penerapan Pengakuan Pendapatan Kontrak Konstruksi Berdasarkan PSAK 34,” J. Ilm. Akunt. Kesatuan, 2019, doi: 10.37641/jiakes.v7i3.298. 